ISTIGHNA, Vol. 1, No 1, Januari 2018 P-ISSN 1979-2824

Homepage: http://e-journal.stit-islamic-village.ac.id/index.php/istighna

Wari Setiawan

Pendidikan Agama Untuk Anak Berkebutuhan Khusus Prespektif Teori Barat dan Islam

\title{
PENDIDIKAN AGAMA UNTUK ANAK BERKEBUTUHAN KHUSUS PERSPEKTIF TEORI BARAT DAN ISLAM
}

\author{
Wari Setiawan \\ (warseserdos2014@gmail.com) \\ Dosen Universitas Islam Negeri (UIN) Syarif Hidayatullah Jakarta
}

\begin{abstract}
Abstrak: Anak Berkebutuhan Khusus (ABK) sebagai makhluk sosial sepatutnya mendapatkan layanan pendidikan yang sebaik-baiknya, termasuk pendidikan agama. Perlakuan terhadap mereka dapat dipahami melalui model medis dan model sosial. Model medis memandang ABK sebagai masalah sosial yang menghambat perkembangan masyarakat sehingga harus dipisahkan dari masyarakat. Model sosial menghendaki perlakuan ABK sebagai makhluk sosial yang harus diperlakukan sama karena punya hak yang sama dalam mendapatkan pendidikan. Begitu pula dengan teori Barat dan fithrah. Teori barat umumnya memandang pendidikan agama bgai mereka tidak perlu, karena agama adalah wilayah privasi. Berbeda dengan teori fithrah, ABK memiliki potensi keagamaan yang harus dikembangkan melalui pendidikan.
\end{abstract}

Kata Kunci: ABK, Model, Teori Barat, dan Fithrah.

\section{A. Pendahuluan}

Pendidikan merupakan hak setiap anak, baik anak normal maupun Anak Berkebutuhan Khusus (ABK). Pelayanan terhadap anak berkebutuhan khusus di Indonesia berada sekolah luar biasa/sekolah khusus dan sekolah inklusi. Pada sekolah khusus, peserta didiknya adalah ABK sementara pada sekolah inklusi terdapat penggabungan antara anak normal dan ABK.

Sekolah Luar Biasa (SLB) atau sekolah khusus dengan berbagai jenjang di Indonesia adalah 1.962, dengan jumlah siswa 114.085 orang. Adapun jumlah keseluruhan guru SLB di Indonesia adalah 24.897 orang. ${ }^{1}$ Statistik ini mengacu pada pusat data statistik Kementrian Pendidikan dan Kebudayaan berdasarkan data Dapodik.

Sementara jumlah guru PAI yang mengajar di SLB atau sekolah khusus dengan memperhatikan tugas mengajarnya adalah 388 orang dengan rincian PAUD (0 orang), TK (43 orang) SD (296 orang), SMP (38 orang), SMA (11

${ }^{1}$ Kemendikbud, Statistik Sekolah Luar Biasa Tahun 2015/2016, (Jakarta: Pusat Data Statistik Pendidikan, 2016), h. 7-8 
ISTIGHNA, Vol. 1, No 1, Januari 2018 P-ISSN 1979-2824

Homepage: http://e-journal.stit-islamic-village.ac.id/index.php/istighna

Wari Setiawan

Pendidikan Agama Untuk Anak Berkebutuhan Khusus Prespektif Teori Barat dan Islam

orang), pada SMK (0 orang). ${ }^{2}$ Jumlah ini sangat kecil bahkan minim. Data ini menunjukkan partisipasi guru untuk PAI sangat minim di sekolah khusus. Perbandingannya adalah 3 orang guru untuk 78 sekolah atau 3 orang guru untuk 4.443 orang. Sebaran yang kecil dan tidak merata ini menunjukkan tidak setiap SLB atau sekolah khusus memiliki guru PAI. Padahal, layanan pendidikan agama merupakan layanan yang harus dipenuhi oleh setiap satuan pendidikan. Data statistik ini menunjukkan pula implikasi masalah pada layanan pembelajaran PAI. Belum lagi, masalah yang berhubungan dengan latar belakang pendidikan guru yang mengajar PAI. Ini diasumsikan akan menimbulkan masalah dalam pembelajaran PAI.

Dalam konteks Islam, setiap anak mempunyai hak yang sama untuk mendapatkan layanan pendidikan. Pembelajaran Pendidikan Agama Islam (PAI), ${ }^{3}$ pada peserta didik yang normal sangat berbeda dengan proses pembelajaran terhadap anak berkebutuhan khusus (ABK). ${ }^{4}$ Akan tetapi, secara umum pendidikan agama (Islam) terhadap anak pada intinya sama, yaitu menjadi manusia yang beriman dan bertakwa melalui pembelajaran dan pembentukan akhlak. ${ }^{5}$ Secara empiris, peserta didik yang normal akan lebih mudah memahami materi pelajaran karena didukung kondisi fisik yang lebih sempurna dibandingkan dengan ABK. Karena tujuan pendidikan agama di antaranya tercapainya sasaran

${ }^{2}$ Kemenag, EMIS 2014/2015 (Jakarta: Ditjen Pendis, 2015), h. 275

${ }^{3}$ Lihat Abuddin Nata, Ilmu Pendidikan Islam dengan Pendekatan Multidisipliner (Jakarta: Rajawali Press, 2010), 1. Dalam hal ini, PAI dimaksudkan untuk menyebutkan mata pelajaran dan pembelajaran di sekolah. Istilah ini mengikat pada konsep salah satu mata pelajaran pada kurikulum sekolah yang mengajarkan agama (Islam) yang berisi materi tentang al-Qur'an, hadits, fiqh, akidah, akhlak, dan sejarah kebudayaan Islam.

${ }^{4}$ Anak berkebutuhan khusus dalam Undang-Undang Nomor 20 tahun 2003 tentang Sistem Pendidikan Nasional pasal 32 ayat 1 disebutkan bahwa pendidikan khusus (pendidikan luar biasa) merupakan pendidikan bagi peserta didik yang memiliki tingkat kesulitan dalam mengikuti proses pembelajaran karena kelainan fisik, emosional, mental, dan sosial. Lihat UU No. 20 tahun 2003. http://kemenag.go.id/file/dokumen/UU2003.pdf. Diakses 30 Mei 2015. Lihat juga UU no. 35 tahun 2014, pasal ayat 7 berbunyi Anak Penyandang disabilitas adalah anak yang memiliki keterbatasan fisik, mental, intelektual, atau sensorik dalam jangka waktu lama yang dalam berinteraksi dengan lingkungan dan sikap masyarakatnya dapat menemui hambatan yang menyulitkan untuk berpartisipasi penuh dan efektif berdasarkan kesamaan hak. http://www.kpai.go.id/files/2013/09/uu-nomor-35-tahun-2014-tentang-perubahan-uu-pa.pdf. Diakses pada 30 Mei 2015.

${ }^{5}$ Ibnu Maskawaih, Tahdzib al-Akhlaq wa Tathir al-'Araq, (Beirut: Mansyurat Dar Maktabah al-Hayat, 1398), 41.Lihat juga Abdullah Nashih Ulwan,Tarbiyah al-Aulad fi al-Islam (Kairo: Darussalam, 1985), cet. Ke-9. Kitab ini juga diterjemahkan juga oleh Jamaluddin Miri, Pendidikan Anak dalam Islam (Jakarta: Pustaka Amani, 2007), cet. Ke-2. 
ISTIGHNA, Vol. 1, No 1, Januari 2018 P-ISSN 1979-2824

Homepage: http://e-journal.stit-islamic-village.ac.id/index.php/istighna

Wari Setiawan

Pendidikan Agama Untuk Anak Berkebutuhan Khusus Prespektif Teori Barat dan Islam

kualitas pribadi, baik sebagai manusia yang beragama maupun sebagai manusia Indonesia yang ciri-cirinya dijadikan tujuan pendidikan nasional. ${ }^{6}$ Dalam konteks ini, tulisan ini akan menguraikan substansi teori pendidikan ABK perspektif teori Barat dan teori Islam.

\section{B. Model Perlakukan Pendidikan ABK}

Perdebatan akademik mengenai pendidikan pada ABK ditengarai pula oleh paradigma model perlakuan. Dalam berbagai literatur ada banyak model disabilitas yang berkembang. Namun sejauh ini ada dua model utama yang banyak dipergunakan, yaitu model medis (medical model) dan model sosial (social model). ${ }^{7}$ Dalam model tersebut, penyandang disabilitas dipandang sebagai masalah. Mereka perlu mengubah dan beradaptasi dengan kondisi ketunaannya (jika mereka bisa), dan tidak ada gagasan bahwa justru masyarakat dan lingkungan yang harus diubah agar dapat mengakomodasi keterbatasan akibat ketunaan individu itu. Dalam model ini, penyandang disabilitas dikategorikan berdasarkan jenis ketunaannya dan jenis dan tempat layanan bagi mereka pun diklasifikasikan berdasarkan ketunaannya. ${ }^{8}$

Sejumlah penelitian yang dilakukan di negara-negara barat menunjukkan bahwa penyandang disabilitas harus menghadapi tantangan personal dan tantangan sosial. Tantangan personal terjadi saat dia harus menghadapi hilangnya fungsi tubuh (terutama pada orang yang mengalami disabilitas di saat dewasa) sebelum akhirnya mencapai tahap penerimaan diri dan kembali menjalani hidup. Rintangan sosial terjadi saat ia harus menghadapi persepsi masyarakat yang terlalu menilai tinggi kesempurnaan ragawi. Rintangan sosial tampaknya lebih mendominasi daripada rintangan personal. Banyak penyandang disabilitas mengungkapkan bahwa tantangan yang mereka hadapi lebih kepada sikap dan

${ }^{6}$ A. Malik Fadjar, Holistika Pemikiran Agama, (Jakarta: Raja Grafindo Persada, 2005), Cet. I, h. 196-197. Lihat juga Harun Nasution, Pendidikan Agama dalam Perspektif Agama-agama (Jakarta: Konsorsium Pendidikan Agama di Pertenaga Pendidikan Tinggi Umum, 1995), Cet. I, 1.

${ }^{7}$ Saharudin Daming, "Komparasi Nilai Penguatan Hak Penyandang Disabilitas dalam Lex Posterior dan Lege Priori”, dalam Jurnal HAM Vol. XIII-Tahun 2016, h. 60

${ }^{8}$ Ibid., h. 61 
ISTIGHNA, Vol. 1, No 1, Januari 2018 P-ISSN 1979-2824

Homepage: http://e-journal.stit-islamic-village.ac.id/index.php/istighna

Wari Setiawan

Pendidikan Agama Untuk Anak Berkebutuhan Khusus Prespektif Teori Barat dan Islam

pandangan masyarakat terhadap mereka daripada beban kondisi fisik mereka sendiri. $^{9}$

Beberapa temuan dalam sejumlah penelitian menunjukkan bahwa penyandang disabilitas berada di bawah strata sosial rata-rata masyarakat. Mereka dianggap kurang normal, atau yang paling buruk, dianggap sebagai manusia yang tidak utuh. Banyak penyandang disabilitas yang merasa bahwa orang-orang melihat seolah-olah mereka menular. Para penyandang kursi roda tentu sering merasa bahwa mereka dilihat semua orang, tapi tidak dianggap oleh siapapun. Ketika berhadapan dengan penyandang disabilitas, kebanyakan orang normal hanya menatap tapi menghindari kontak mata, enggan berbicara langsung, terlihat gelisah jika harus berinteraksi dengan mereka, enggan tersenyum, atau berpurapura bahwa disabilitas itu tidak ada. Di Indonesia, jika melihat seorang penyandang disabilitas, ibu-ibu hamil punya kebiasaan mengelus perut mereka sambil mengucapkan kata-kata yang menyiratkan agar bayi mereka tidak mengalami kondisi seperti itu. ${ }^{10}$

Lawan dari teori medis adalah teori sosial. Model ini tidak menyangkal bahwa perbedaan individual tertentu mengakibatkan keterbatasan individual atau ketunaan, tetapi hal ini bukan merupakan penyebab individu itu dieksklusifkan. Pendekatan ini berasal dari tahun 1960-an dalam pergerakan hak sipil Penyandang Disabilitas/pergerakan Hak Asasi Manusia (HAM) dan istilah social model itu sendiri muncul dari Inggris pada tahun 1980-an. Pada tahun 1976, organisasi Inggris Union of the Physically Impaired Against Segregation (UPIAS) menyatakan bahwa disabilitas merupakan ketidakberuntungan atau keterbatasan kegiatan yang diakibatkan oleh karena masyarakat kurang atau tidak peduli terhadap orang yang menyandang ketunaan fisik dan karenanya mengeksklusifkan mereka untuk berpartisipasi dalam kegiatan sosial di masyarakat umum. ${ }^{11}$

Pada tahun 1983, akademisi penyandang disabilitas Mike Oliver menggunakan istilah social model of disability untuk mengacu pada perkembangan ideologi ini. Oliver mempertentangkan antara model individual (di

\footnotetext{
${ }^{9}$ Ibid., h. 62

${ }^{10}$ Ibid., h. 67

${ }^{11} \mathrm{http}: / /$ id.wikipedia.com
} 
ISTIGHNA, Vol. 1, No 1, Januari 2018 P-ISSN 1979-2824

Homepage: http://e-journal.stit-islamic-village.ac.id/index.php/istighna

Wari Setiawan

Pendidikan Agama Untuk Anak Berkebutuhan Khusus Prespektif Teori Barat dan Islam

mana model medis merupakan salah satu bagiannya) dengan model sosial, yang awalnya berasal dari perbedaan antara impairment (ketunaan) dan disability yang dikemukakan oleh UPIAS. Berdasarkan model sosial, disabilitas disebabkan oleh masyarakat tempat kita tinggal dan bukan merupakan kesalahan seorang individu penyandang disabilitas itu, atau juga bukan merupakan konsekuensi yang tak dapat dihindari dari keterbatasannya. Disabilitas merupakan akibat dari hambatan hambatan fisik, struktural dan sikap yang ada di dalam masyarakat.

Kesetaraan merupakan satu aspek fundamental dari model sosial. Perjuangan untuk memperoleh kesetaraan bagi penyandang disabilitas sering kali dibandingkan dengan perjuangan kelompok-kelompok lain yang secara sosial termarjinalisasi. Kesamaan hak diyakini akan memberikan pemberdayaan dan kemampuan untuk membuat keputusan dan kesempatan untuk menjalani kehidupan secara optimal. Satu slogan yang sering digunakan oleh para pejuang hak asasi penyandang disabilitas adalah nothing about us without us (tak ada tentang kami tanpa kami). Ini berarti bahwa segala keputusan yang menyangkut Penyandang Disabilitas harus dibuat dengan mengikutsertakan mereka. Pembelajaran terhadap anak berkebutuhan khusus, tidak terlepas dari masalah yang muncul. Di antara beberapa masalah yang muncul adalah:

1. Perhatian yang tidak intens terhadap anak berkebutuhan khusus terutama pada anak SLB dengan berbagai tipenya.

2. Partisipasi yang lemah dari orang tua untuk memperhatikan pola pembelajaran mereka di SLB.

3. Lemahnya implementatif kebijakan yang mengatur pendidikan pada SLB terutama terkait dengan pendidikan agama Islam.

4. Masih terdapat stigma negatif pada anak di SLB.

Keberhasilan pembelajaran ABK selain ditentukan oleh pembelajaran di sekolah, dipengaruhi pula oleh persepsi orang tua (keluarga) terhadap eksistensi ABK. Hasil riset Rima Rizki Anggraeni di salah satu SDLB di Kota Solok menunjukkan terdapat kekecewaan orang tua terhadap anak berkebutuhan khusus, 10 orang tua $(34,48 \%)$ atau hampir sebagian orang tua sangat kecewa karena anaknya tergolong ABK tidak memenuhi apa yang diharapkan. Sedangkan 
ISTIGHNA, Vol. 1, No 1, Januari 2018 P-ISSN 1979-2824

Homepage: http://e-journal.stit-islamic-village.ac.id/index.php/istighna

Wari Setiawan

Pendidikan Agama Untuk Anak Berkebutuhan Khusus Prespektif Teori Barat dan Islam

sebanyak 19 orang tua $(65,51 \%)$ sebagian besar orangtua tidak sangat kecewa karena anaknya tergolong ABK tidak memenuhi apa yang diharapkan. ${ }^{12}$

Perasaan orang tua meliputi perasaan bersalah, dan kurang berhati-hati pada saat mengandung muncul sebanyak 13 orang tua $(44,82 \%)$ atau hampir sebagian orang tua meliputi perasaan bersalah, mungkin kurang berhati-hati pada saat mengandung anaknya, atau kurang berhati-hati dalam menggunakan obat. Sedangkan sebanyak 16 orang tua $(55,17 \%)$ atau sebagian besar menyatakan tidak diliputi perasaan bersalah, mungkin kurang berhati-hati pada saat mengandung anaknya, atau kurang berhati-hati dalam menggunakan obat.

Orangtua merasa bersalah dan merasa bertanggung jawab atas kecacatan anak, sebanyak 20 orang tua $(68,96 \%)$ atausebagian besar orangtua merasa bersalah, kemudian merasa bertanggung jawab atas kecacatan atau hambatan anaknya $(\mathrm{ABK})$ dan bersikap amat melindungi. Sedangkan sebanyak 9 orang tua $(31,03 \%)$ hampir sebagian orang tua tidak merasa bersalah, kemudian merasa bertanggung jawab atas kecacatan atau hambatan anaknya (ABK) dan bersikap amat melindungi.

Orang tua merasa malu kepada anak berkebutuhan khusus, sebanyak 17 orang tua $(58,62 \%)$ atau sebagian besar orang tua merasa malu dengan kehadiran anak berkebutuhan khusus (ABK). Sedangkan sebanyak 12 orang tua $(41,37 \%)$ atau hampir sebagian orang tua tidak merasa malu dengan kehadiran anak berkebutuhan khusus (ABK). Penelitian diarahkan tidak pada sekolah inklusi melainkan pada sekolah khusus dengan pertimbangan:

1. Sekolah khusus atau SLB relatif telah mengakar dalam pandangan masyarakat untuk pendidikan bagi anak difabel.

2. Sekolah khusus sudah berjalan lebih lama daripada sekolah dengan tipe inklusi.

3. Minimnya perhatian terhadap anak-anak difabel.

\footnotetext{
${ }^{12}$ Rima Rizki Anggraeni, Persepsi Orang Tua terhadap Anak Berkebutuhan Khusus, dalam Jurnal Ilmiah Pendidikan Khusus Vol.1 Nomor 1 Januari 2013, h. 258
} 
ISTIGHNA, Vol. 1, No 1, Januari 2018 P-ISSN 1979-2824

Homepage: http://e-journal.stit-islamic-village.ac.id/index.php/istighna

Wari Setiawan

Pendidikan Agama Untuk Anak Berkebutuhan Khusus Prespektif Teori Barat dan Islam

4. Perlunya penelaahan ulang terhadap interaksi pembelajaran di sekolah khusus dengan penekanan pengembangan pembelajaran yang sesuai dengan tipikal anak.

\section{Pendidikan Agama untuk ABK Perspektif Barat: Nativisme, Naturalisme, Liberalisme, Psikoanalisis, dan Atheisme}

Meskipun kewajiban tentang penanaman pendidikan agama terhadap anak banyak disambut banyak orang, tetapi sebagian terdapat yang menolak praktik pendidikan religius terhadap setiap manusia. Di antara tokoh yang menolak pendidikan religius adalah Arthur Schopenhauer, seorang penganut teori nativisme atau pesimisme. Menurutnya, pendidikan akhlak adalah musuh kehidupan yang selalu mengikat kehidupan dengan penuh penderitaan. Sejatinya seseorang harus membebaskan diri dari penderitaan tersebut dengan cara hidup bebas tanpa diikat dengan rantai moral. ${ }^{13}$ Dengan kata lain, seorang anak sejak lahir telah membawa sifat-sifat tertentu yang akan menentukan keadaan individu yang bersangkutan dan ia dapat membentuk akhlaknya dan kepribadiannya sendiri tanpa faktor lingkungan dan campur tangan manusia.

Selain Schopenhauer, terdapat JJ. Rousseau yang menganut teori negativisme atau naturalisme yang mengatakan bahwa seorang anak memiliki pembawaan yang baik. Ia rusak disebabkan oleh pendidikan manusia sehingga ia harus diserahkan kepada alam. Agar seorang anak dapat tumbuh dengan sendirinya tanpa ada campur tangan manusia. ${ }^{14}$ Teori-teori tersebut tidak berlaku pada pendidikan anak yang berkebutuhan khusus. Karena pengembangan nilainilai pendidikan akhlak atau religiusitas, ${ }^{15}$ terhadap anak-anak berkebutuhan khusus seperti spiritual, moral, budaya, mental dan kejiwaan pada setiap anak didasarkan pada nilai dan kebaikan tradisi masyarakat. Peniliain tersebut seperti cinta tetangga, cinta kebenaran dan keadilan, pelaksanaan hak dan kewajiban,

\footnotetext{
${ }^{13}$ Frans Magniz Suseno, 13 Tokoh Etika (Yogyakarta: Kanisius, 1997), h. 171

${ }^{14}$ Fuad al-Ahwani, al-Tarbiyah al-Islamiyah (Kairo: Dar al-Ma'arif, 2008), h. 67

${ }^{15}$ Damanhuri, Akhlak Perspektif Pemikiran Tasawuf Abdurrauf As-Singkili (Banda Aceh: Ar-Rijal Publisher, 2011), 1. Lihat juga Ibrahim Anis, Al-Mu'jam al-Wasith (Kairo: Dar alMa'arif, 1972), h. 2. Bandingkan juga dengan M. Quraish Shihab, Wawasan Al-Quran: Tafsir Maudhu'i Atas Pelbagai persoalan Umat (Bandung: Mizan, 1996), h. 261. Lihat juga Ibn Miskawaih, Mепијu Kesempurnaan Akhlak (Bandung: Mizan, 1994), h. 56
} 
ISTIGHNA, Vol. 1, No 1, Januari 2018 P-ISSN 1979-2824

Homepage: http://e-journal.stit-islamic-village.ac.id/index.php/istighna

Wari Setiawan

Pendidikan Agama Untuk Anak Berkebutuhan Khusus Prespektif Teori Barat dan Islam

pengamalan kebaikan dan pemberian maaf. ${ }^{16}$ Nilai-nilai pendidikan seperti ini dapat dikembangkan melalui empat strategi. Pertama, pengembangan spiritual terintegrasi melalui kurikulum dan praktik ibadah sehari-hari. Kedua menumbuhkan moral setiap anak dengan membentuk karakter sehingga menimbulkan keberanian melakukan kebenaran. Ketiga pembentukan budaya dengan menggabungkan warisan agama sebagaimana kontribusi agama lain dan budaya. Keempat pembangunan mental dan kejiwaan yang melahirkan potensi anak untuk tumbuh dalam bayangan Tuhan. ${ }^{17}$ Aliran psikonalisis yang dijelaskan oleh Sigmund Freud menyatakan bahwa manusia pada dasarnya tidak baik, dan berwatak buruk. ${ }^{18}$ Psikoanalisis menyebutkan asumsi unconcious motivation yang meyakini bahwa sebagian besar tingkah laku individu ditentukan oleh motif tak sadar. Kesadaran hanya merupakan sebagian kecil saja dari seluruh kehidupan psikis. Diumpamakan psyche itu sebagai gunung es di tengah lautan, yang ada di permukaan air laut itu menggambarkan kesadaran. Sedangkan yang di bawah permukaan air laut itu yang merupakan bagian terbesar yang menggambarkan ketidaksadaran. Peran penting dari ketidaksadaran dalam pengaturan tingkah laku menjadi temuan monumental bagi Frued. ${ }^{19}$ Implikasi teori ini dalam pendidikan menyiratkan bahwa peserta didik yang mengubah perilaku sebenarnya lebih dipengaruhi oleh ketidaksadaran, bukan sebagai akibat kesadaran dan bentukan

${ }^{16}$ Lihat Muhammad Yusuf Musa, Falsafah al-Akhlaq fi al-Islam (Kairo: Muassasat alKanji, 1963), 5. Lihat juga M. Amin Abdullah, The Idea of Universality of Ethical Norms In Ghazali and Kant, diterjemahkan oleh Hamzah dengan judul, Antara Al-Ghazali dan Kant: Filsafat Etika Islam (Bandung: Mizan, 2002), h. 25

${ }^{17}$ Lihat Kurnali, Pengembangan Pendidikan Agama Islam Sebagai Budaya Dalam Pembentukan Karakter Siswa: Studi Kasus di SMP Islam PB. Soedirman Jakarta (Magelang: PKBM Ngudi Ilmu, 2014), h. 91-92. Lihat pula Nurcholish Madjid, Islam Doktrin dan Peradaban: Sebuah Telaah tentang Keimanan, Kemanusian dan Kemoderenan (Jakarta: Paramadina, 1992), h. 16. Lihat juga Tobroni dan Syamsul Arifin, Islam Pluralisme Budaya dan Politik: Refleksi Teologi untuk Aksi dalam Keberagamaan dan Pendidikan, (Yogyakarta: Siprres, 1994), h. 6. Lihat juga Umar Sulaiman, Islam Kosmopolit: Ikhtiar Pembumian Nilai-Nilai Transenden dan Humanis di Ruang Publik (Yogyakarta: Fresh Book, 2012), h. 35. Lihat juga Bayraktar Bayrakli, Eksistensi Manusia: Perspektif Tasawuf dan Filsafat Mengatasi Problema Eksistensial Manusia Jalaluddin Rumi Sampai Filosof Kontemporer (Jakarta: Perenial Press, 1997), h. 12. Bandingkan juga Sachiko Murata, The Tao of Islam: Kitab Rujukan tentang Relasi Gender dalam Kosmologi dan Teologi Islam, (Bandung: Mizan, 2000), h. 80.

${ }^{18}$ Syamsu Yusup, Teori Kepribadian, (Bandung: Rosda Karya, 2010), h. 143

${ }^{19}$ Lihat Harlock, Personality Development, (New York: Mc Millan, 2010), h. 32. Lihat pula Sihabul Badri, Teori Psikoanalisis Sigmund Freud, (Bandung: UIN Bandung, 2010), h. 4 
ISTIGHNA, Vol. 1, No 1, Januari 2018 P-ISSN 1979-2824

Homepage: http://e-journal.stit-islamic-village.ac.id/index.php/istighna

Wari Setiawan

Pendidikan Agama Untuk Anak Berkebutuhan Khusus Prespektif Teori Barat dan Islam

interaksi sosial. ${ }^{20}$ Aliran psikonalisis ini memandang bahwa pendidikan agama yang bersifat privasi tidak dibutuhkan. Manusia menurutnya dapat mengenal Tuhan ketika ia berada pada tahap penyesalan sebagaimana penjelasan dalam kisah Odipus Complex.

Pendidikan agama menjadi kritik pula dari kaum liberalis dengan pemikiran liberalisme. Menurut mereka, manusia bebas untuk menentukan tindakan tanpa ada sekat atau ikatan moral. Pendidikan agama bersifat privasi dan tidak bisa diformalkan melalui sekolah atau lembaga. Agama dalam pandangan mereka tidak dipaksa untuk diajarkan. Sebab agama adalah dorongan pribadi antara dirinya dengan yang dianggap sebagai Tuhan. Dalam konteks ini, penanaman nilai keagamaan tidak perlu diformalkan atau dijadikan materi dalam kurikulum. ${ }^{21}$

Aliran tersebut cukup longgar dalam memandang norma sebagai ikatan. Substansi bagi aliran ini adalah manusia berhak untuk mewujudkan perilaku, tindakan, dan aktualisasi diri tanpa harus dikungkung oleh pesan-pesan Tuhan. Pemikiran ini dianggap mengabaikan nilai religius, bahkan meninggalkannya. Implikasinya adalah bentukan nilai religius tidak berdasarkan sentuhan pendidikan yang teratur, melainkan dorongan ego masing-masing.

Ketika kebebasan itu berlebihan, nilai dan norma budaya lokal dan nasional, terlebih nilai agama, akan terancam olehnya. Kebebasan di sini bukan berarti kebebasan bermakna positif seperti kebebasan berfikir, melainkan kebebasan yang menjurus pada kepuasan lahiriyah (hedonis) dan egoisme. Akibat negatif kebebasan seperti ini muncul kebebasan seks, kebebasan penyalahgunaan narkotika, dan sejenisnya. Kebebasan negatif selalu menjadi akibat atau bahkan juga menjadi sebab dalam mendapatkan keuntungan materi. ${ }^{22}$

Kritik yang paling ekstrim muncul dalam pemikiran atheistik. Pemikiran ini meniadakan keberpihakan dan keterlibatan Tuhan dalam kehidupan manusia, bahkan menafikan eksistensi Tuhan. Pendidikan agama mengajarkan manusia

\footnotetext{
${ }^{20}$ Nick Rennison, Freud and Psychoanalysis, (London: Pdunk, 2010), h. 10

${ }^{21}$ Rudi Ahmad Suryadi, Ghayah al-Tarbiyah fi Dhau' al-Qur'an al-Karim, (Bandung: UIN Bandung, 2011), h. 8-12

${ }^{22}$ Qadri Azizy, Melawan Globalisasi: Reinterpretasi Ajaran Islam Persiapan SDM dan Terciptanya Masyarakat Madani, (Yogyakarta: Pustaka Pelajar, 2004), cet.ke-1, h. 20
} 
ISTIGHNA, Vol. 1, No 1, Januari 2018 P-ISSN 1979-2824

Homepage: http://e-journal.stit-islamic-village.ac.id/index.php/istighna

Wari Setiawan

Pendidikan Agama Untuk Anak Berkebutuhan Khusus Prespektif Teori Barat dan Islam

untuk mengenal Tuhannya. Berbeda dengan anggapan atheistik, yang menafikan Tuhan. Ketika pendapat ekstrim ini dijadikan titik tolak pemikiran pendidikan, maka akan muncul pernyataan bahwa Tuhan saja tidak berhak untuk dikenal, apalagi pendidikan agama.

Pemikiran sekularisasi dan sekularisme memiliki dampak menjauhkan pengaruh agama terhadap kehidupan. Kenyataan ini tampak sekali, misalnya dalam bentuk membolehkan perzinaan dan tidak menganggapnya sebagai dosa jika dilakukan atas kerelaan kedua belah pihak. Demikian juga dengan free sex dan memberi legalitas kepada dekadensi moral dan kebebasan tanpa kendali. Sehingga mereka kehilangan pegangan hidup, putus asa, dan kenikmatan kehidupan ini hanya kenikmatan materi semata. Pemikiran sekularisme tidak menghendaki pendidikan agama di sekolah atau lembaga yang diformalisasikan, seperti halnya pemikiran liberalisme.

Pemaparan beberapa paragraf di atas menunjukan perdebatan akademik mengenai signifikansi pendidikan agama bagi setiap anak. Pemikiran nativisme, naturalisme, liberalisme, psikoanalisis, dan atheisme menghendaki penolakan pendidikan agama secara formalistik pada anak, termasuk untuk Anak Berkebutuhan Khusus (ABK). Sementara, dalam konsep fithrah, anak dapat dididik sesuai dengan lingkungan dan pendekatan tertentu.

\section{Perspektif Fithrah mengenai Pendidikan Agama untuk ABK}

Dalam konteks Islam, peserta didik dipandang sebagai makhluk Tuhan dengan fitrah yang dimiliki, sebagai makhluk individu dan makhluk sosial yang sempurna dan memiliki sifat yang unggul. ${ }^{23}$ Pendidikan tidak terkecuali juga harus diajarkan kepada anak berkebutuhan khusus. ${ }^{24}$

Dengan demikian pendidikan agama Islam tidak hanya mengandung konten tentang ajaran agama pada peserta didik. Dalam kaitan dengan ABK, secara filosofis terdapat nilai-nilai untuk menegaskan kesamaan peserta didik yang normal dan ABK. Kedua jenis peserta didik ini memiliki nilai sama dalam konsep ketuhanan. Mereka adalah makhluk-Nya dan menjadi amanah bagi kedua orang

${ }^{23}$ Zainal Abidin, Filsafat Manusia, (Bandung: PT Remaja Rosdakarya, 2002), h. 45

${ }^{24}$ Lihat juga Fadhal AR. Bafadal, Al-Qur'an dan Tafsirnya, (Semarang: CV. Al Waah, 2004), h. 864. Lihat juga QS Ibrahim: h. 1. 
ISTIGHNA, Vol. 1, No 1, Januari 2018 P-ISSN 1979-2824

Homepage: http://e-journal.stit-islamic-village.ac.id/index.php/istighna

Wari Setiawan

Pendidikan Agama Untuk Anak Berkebutuhan Khusus Prespektif Teori Barat dan Islam

tuanya. Dalam hal ini, pendidikan ABK harus diperhatikan lebih baik, sebagaimana pendidikan untuk anak normal dan hal ini telah disinggung oleh alQur'an sebagai berikut:

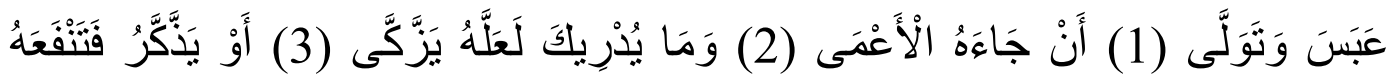

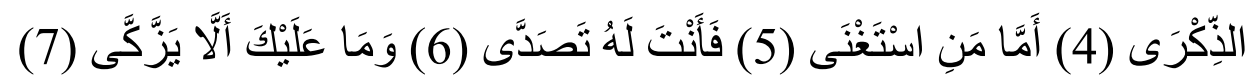
Artinya: "Dia (Muhammad) bermuka masam dan berpaling, karena telah datang seorang buta kepadanya. Tahukah kamu barangkali ia ingin membersihkan dirinya (dari dosa). atau dia (ingin) mendapatkan pengajaran, lalu pengajaran itu memberi manfaat kepadanya?, Adapun orang yang merasa dirinya serba cukup, maka kamu melayaninya. Padahal tidak ada (celaan) atasmu kalau dia tidak membersihkan diri (beriman). (QS ‘Abasa [80]: 1-7)

Dalam pandangan Ibnu Katsir mayoritas mufassirin menjelaskan bahwa sebab turun ayat tersebut terkait dengan komunikasi rasulullah Saw terhadap para pembesar Quraish yang saat itu diharapkan oleh rasulullah Saw akan masuk Islam. Saat rasulullah sedang memberikan pengarahan tentang agama Islam, tibatiba Abdullah Ibnu Umi Maktum datang dan sepertinya rasulullah Saw tidak menghendaki kehadirannya sehingga ia bermuka masam dan berpaling darinya. Kontan setelah itu Allah Swt menegur tindakan rasulullah Saw dan menurunkan ayat ini. ${ }^{25}$ Dari sini-menurut Ibnu Kathir- Allah Swt memerintahkan kepada rasulullah Saw agar tidak membeda-bedakan antara sosok yang mulia dan hina, miskin dan kaya, majikan dan pelayan, laki-laki dan perempuan atau laki-laki dan anak-anak serta orang dewasa. ${ }^{26}$

Dalam realisasinya rasulullah Saw mendengar teguran tersebut dan setelah itu ia selalu menyambut kedatangan Abdullah Ibnu Umi Maktum dengan penuh suka cita. Setiap ia datang rasulullah Saw kerap mengucapkan; 'Selamat datang dengan sosok yang Allah Swt menegurku karenanya”. Rasulullah Saw kerap

${ }^{25}$ Ibnu Katsir, Tafsir Ibnu Kathir, (Cairo:Dar al-Shabuni, tt), h. 599
${ }^{26}$ Ibid. 
ISTIGHNA, Vol. 1, No 1, Januari 2018 P-ISSN 1979-2824

Homepage: http://e-journal.stit-islamic-village.ac.id/index.php/istighna

Wari Setiawan

Pendidikan Agama Untuk Anak Berkebutuhan Khusus Prespektif Teori Barat dan Islam

mencari informasi tentang Abdullah Ibnu Umi Maktum setiap ia tidak terlihat di kota Madinah. $^{27}$

Realitas di atas menunjukkan betapa Islam-yang diwakili oleh rasulullah Saw dalam hal ini- sangat menjunjung persamaan hak, khususnya tentang pembelajaran agama Islam, baik bagi orang-orang normal dan orang-orang yang berkebutuhan khusus seperti Abdullah Ibnu Umi Maktum itu.

Bahkan Sayid Qutb menyatakan bahwa awal surat 'Abasa merupakan deklarasi reallitas nilai mengenai kehidupan umat Islam dengan redaksi yang kuat sekaligus deklarasi realitas dakwah Islam kepada umat umatnya. Hal ini bukan semata-mata realitas bagaimana cara berinteraksi dengan seseorang atau interaksi dengan orang-orang tertentu, melainkan bagaimana seseorang menimbangnimbang seluruh unsur kehidupan dan dari mana mereka mengambil nilai-nilai ketika mereka hendak memutuskan suatu hal. ${ }^{28}$

Dengan asumsi lain ayat-ayat di atas merupakan anjuran agar seseorang mengambil tuntunan kehidupan dari al-Quran yang turun dari langit, bukan dari ajaran bumi, kehidupan atau persepsi manusia tentang kehidupan itu sendiri. Hal ini merupakan realitas yang mulia tetapi sulit. Mulia, karena hal itu memang yang seharusnya. Sulit, karena manusia selalu berinteraksi dengan kebiasaan dan persepsi mereka sendiri sehingga sulit melaksanakannya. ${ }^{29}$ Persamaan hak juga dinyatakan oleh al-Quran dalam ayat lain surat al-Hujurat ayat 13.

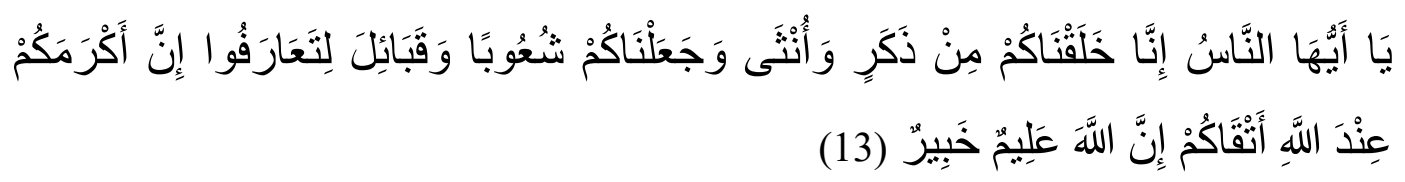

Artinya: "Hai manusia, sesungguhnya Kami menciptakan kamu dari seorang lakilaki dan seorang perempuan dan menjadikan kamu berbangsa-bangsa dan bersuku-suku supaya kamu saling kenal mengenal. Sesungguhnya orang yang paling mulia di antara kamu di sisi Allah ialah orang yang paling bertakwa di antara kamu. Sesungguhnya Allah Maha Mengetahui lagi Maha Mengenal. (QS al-Hujurat [49]:13)

\footnotetext{
${ }^{27}$ Muhammad al-Ghazali, Nahwa Tafsir Maudhui li Suwari al-Quran al-Karim (Beirut: Dar al-Shuruq, 2011), h. 500

${ }^{28}$ Sayid Quthb, Fi Zilali al-Qur'an, (Beirut: Dar al-Shuruq, 1992), h. 3822-3833

${ }^{29}$ Ibid., h. 3833
} 
ISTIGHNA, Vol. 1, No 1, Januari 2018 P-ISSN 1979-2824

Homepage: http://e-journal.stit-islamic-village.ac.id/index.php/istighna

Wari Setiawan

Pendidikan Agama Untuk Anak Berkebutuhan Khusus Prespektif Teori Barat dan Islam

Selain itu konsep fitrah memandang bahwa manusia pada dasarnya adalah baik. Manusia berasal dari Tuhan yang baik, diberi potensi untuk berbuat baik melalui rambu-rambu kebaikan, dan kembali kepada Tuhan dalam keadaan baik. Dalam konteks pendidikan, potensi fitrah ini penting untuk dikembangkan baik untuk peserta didik yang normal maupun berkebutuhan khusus. Sebagaimana dijelaskan dalam Hadits Rasulullah SAW (isyarah annas) sebagai berikut:

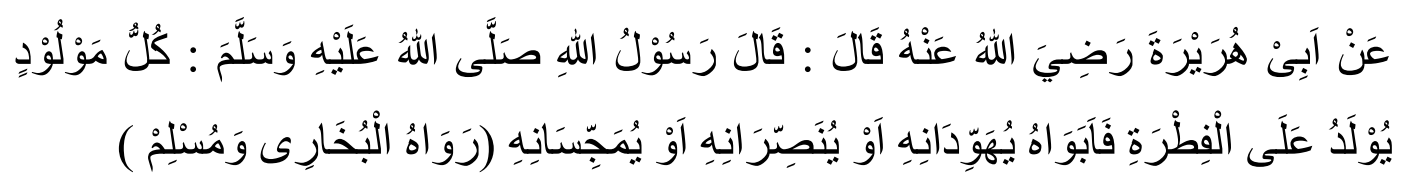

Artinya: "Dari Abu Hurairah R.A, Ia berkata: Rasulullah SAW bersabda :

"Setiap anak dilahirkan dalam keadaan suci, ayah dan ibunyalah yang menjadikan Yahudi, Nasrani, atau Majusi." (HR. Bukhari dan Muslim) $)^{30}$

Fithrah adalah potensi dasar manusia. Artinya, setiap manusia memiliki beberapa potensi itu, dan ia diberi kebebasan untuk mengembangkan potensi mana yang ia sukai, sebagaimana dikemukakan oleh Ramayulis dalam buku Ilmu Pendidikan Islam. ${ }^{31}$ Menurut Ibnu Khaldûn, manusia lahir membawa kemampuan yang terpendam yang disebut fithrah. Fithrah manusia cenderung kepada Islam dan lingkungan (termasuk orang tua dan masyarakat), di mana ia berada sangat mempengaruhi perkembangan akal dan jiwa peserta didik. Seolah-olah Ibnu Khaldûn ingin menegaskan, bahwa di samping faktor bakat dan keturunan, juga ada faktor lain yang mempengaruhi perkembangan akal dan jiwa anak didik, yaitu faktor lingkungan. ${ }^{32}$

Dari sini terlihat bahwa pendapatnya Ibnu Khaldûn tersebut, sependapat dengan filosof muslim yang lain seperti Ibnu Miskawaih dan telah mendahului pahamnya konvergensi William Stern. ${ }^{33}$ Bahkan Ibnu Khaldûn membantah pendapatnya aliran empirisme John Locke, yang berpendapat bahwa hanya faktor lingkungan saja yang berpengaruh dalam perkembangan pribadi seseorang, dan

\footnotetext{
${ }^{30}$ Abdullah Nashih Ulwan, Pendidikan Anak Dalam Islam ( Jakarta: Pustaka Amani 2007), h. 171

${ }^{31}$ Ramayulis, Ilmu Pendidikan Islam, (Jakarta: Kalam Mulia, 2006), h. 278

${ }^{32}$ Heris Hermawan, Filsafat Pendidikan Islam, (Jakarta: Diktis, 2008), h. 34

${ }^{33}$ Lihat Busyairi Majdidi, Konsep Kependidikan para Filosof Muslim, (Yogyakarta: alAmin, 1997) juga Hery Noer Aly, Ilmu Pendidikan Islam, (Jakarta: Logos, 2008)
} 
ISTIGHNA, Vol. 1, No 1, Januari 2018 P-ISSN 1979-2824

Homepage: http://e-journal.stit-islamic-village.ac.id/index.php/istighna

Wari Setiawan

Pendidikan Agama Untuk Anak Berkebutuhan Khusus Prespektif Teori Barat dan Islam

aliran nativisme Schopenhauer, yang berpendapat faktor pembawaan atau warisan yang sangat berpengaruh terhadap perkembangan potensi seseorang. ${ }^{34}$

Selain itu juga, peserta didik dalam pandangan Ibnu Khaldûn adalah sosok yang harus diperhatikan. Ia menempatkan peserta didik sebagai sosok yang harus dipahami dan diikuti perkembangan kejiwaan dan akal pikirannya, karena peserta didik pada awal kehidupannya belum memiliki kematangan pertumbuhan. Karena peserta didik memiliki perbedaan antara individu dengan individu yang lain, baik yang meliputi segi jasmani, intelegensi, sosial, bakat, minat, dan lingkungan yang mempengaruhinya. ${ }^{35}$

Ibnu Khaldûn menghendaki peserta didik diberikan pengajaran dan pengetahuan dengan memperhatikan prinsip-prinsip kemampuan atau potensi yang ada di dalam peserta didik akan menerima ilmu pengetahuan tersebut. Dengan kata lain, bahwa dalam proses pentransferan pengetahuan kepada peserta didik hendaknya didasarkan kepada perkembangan psikologis peserta didik. Dalam hal ini Ibnu Khaldûn berpendapat betapa pentingnya memperhatikan perkembangan akal anak didik dan kemampuan mereka menerima berbagai ilmu dan keterampilan yang diajarkan oleh pendidik. Hal ini disebabkan karena ia berkeyakinan, bahwa proses pengajaran tidak akan berhasil dengan baik, kecuali setelah mempelajari tabiat akal manusia pada berbagai periode perkembangan, karena seorang anak pada awal kehidupannya belum sempurna cara berpikirnya, ia belum mampu memahami pelajaran secara keseluruhan. Justru karena itu, seorang pendidik perlu mengulang-ulang materi yang diberikan dengan mempergunakan contoh-contoh yang hidup dalam bentuk yang sederhana menuju kepada yang lebih sempurna (secara bertahap, gradual) dengan memperhatikan kemampuan dan kesiapan anak didik. ${ }^{36}$

Muhibbin Syah dalam hal ini memandang peserta didik berkembang setingkat demi setingkat atau setahap demi setahap mengikuti alur perkembangannya. Dari tingkat-tingkat perkembangan tersebut, dapat diketahui secara jelas pada awal periode belajar yang nampak lemah dalam menerima dan

\footnotetext{
${ }^{34}$ Heris Hermawan, Loc. Cit., h. 34

${ }^{35}$ Ibid., h. 35

${ }^{36}$ Heris Hermawan, Filsafat Pendidikan Islam, Op. Cit., 37
} 
ISTIGHNA, Vol. 1, No 1, Januari 2018 P-ISSN 1979-2824

Homepage: http://e-journal.stit-islamic-village.ac.id/index.php/istighna

Wari Setiawan

Pendidikan Agama Untuk Anak Berkebutuhan Khusus Prespektif Teori Barat dan Islam

memahami pengetahuan yang diajarkan kepadanya, terutama bila yang diajarkan adalah masalah yang sulit untuk dipahami. Karena belajar itu merupakan aktivitas yang berproses, sudah tentu di dalamnya terjadi perubahan-perubahan yang bertahap pula. Perubahan tersebut timbul melalui tahapan-tahapan yang antara satu dengan lainnya bertalian secara berurutan dan fungsional. ${ }^{37}$

Atas dasar inilah Ibnu Khaldûn, sebagaimana dikemukakan Heris Hermawan mengkritik secara tegas sikap atau perilaku pendidik yang tidak menguasai metode-metode pendidikan yang terbaik. Tindakan pendidik seperti ini sangat berbahaya terhadap pribadi peserta didik, terutama jika mereka berusia muda, karena tidak membantu mempersiapkan situasi dan kondisi bagi peserta didik untuk menampakkan jati dirinya dan menimba pengetahuan serta pengalaman atas kesadaran pribadi. Hal ini dapat dinyatakan bahwa proses pengajaran seperti ini tidak akan dapat mencapai tujuan yang diinginkan, karena hanya semata-mata proses pengajaran dari pihak guru yang terfokus pada penjejalan pengetahuan bagi peserta didik, tanpa memperhatikan adanya proses belajar dari peserta didik itu sendiri. ${ }^{38}$

Selain QS al-Hujurat ayat 13 dan 'Abbasa di atas, terdapat ayat yang bersentuhan pula dengan pendidikan untuk ABK, seperti QS al-Hajj: 5

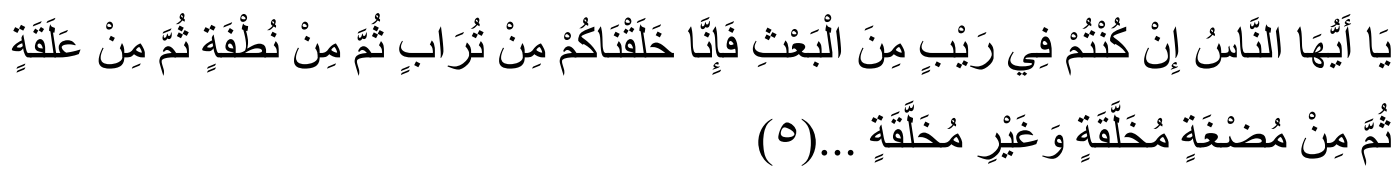

Artinya: “Wahai manusia! Jika kamu meragukan (hari) kebangkitan, maka sesungguhnya Kami telah menjadikan kamu dari tanah, kemudian dari setetes mani, kemudian dari segumpal darah, kemudian dari segumpal daging yang sempurna kejadiannya dan yang tidak sempurna... (QS.alHajj [22]:5)

Kata وَغَنَرِ مُخَلَّقَةٍ yang diterjemahkan menjadi “dan yang tidak sempurna” memiliki makna bahwa embrio atau janin terdapat yang berbentuk tidak sempurna. Ketidaksempurnaan ini berhubungan dengan ketidaksempurnaan fisik.

${ }^{37}$ Muhibbin Syah, Psikologi Pendidikan dengan Pendekatan Baru, (Bandung: Rosda Karya, 2007), 98

${ }^{38}$ Heris Hermawan, Loc. Cit., h. 37 
ISTIGHNA, Vol. 1, No 1, Januari 2018 P-ISSN 1979-2824

Homepage: http://e-journal.stit-islamic-village.ac.id/index.php/istighna

Wari Setiawan

Pendidikan Agama Untuk Anak Berkebutuhan Khusus Prespektif Teori Barat dan Islam

Kondisi ini menyebabkan bayi yang dilahirkan memiliki ketidaksempurnaan dalam bentuk fisik, terutama misalnya pada unsur fisiologis yang menopang kehidupan. Fenomena pasca kelahiran sampai berkembang menjadi anak-anak bersentuhan dengan kenyataan tentang difabilitas ABK. Ayat ini terutama pada kata yang ditentukan tadi, bersentuhan dengan fenomena dan perhatian terhadap anak-anak yang lahir dalam keadaan tidak sempurna, dan tetap memiliki hak fitrah dan pendidikan seperti halnya anak normal.

Abdul Mujib memandang bahwa fithrah merupakan citra asli manusia. Fithrah memiliki potensi baik dan buruk yang diaktualisasikan tergantung pilihan manusia sendiri. Fithrah yang baik menurutnya, merupakan citra asli yang primer, sedangkan fithrah yang buruk merupakan citra asli yang sekunder. ${ }^{39}$ Hal ini berbeda dengan malaikat yang hanya memiliki fithah baik, atau syaitan yang hanya memiliki fithrah buruk, atau juga hewan dan tumbuhan serta benda lainnya yang tidak memiliki fithrah baik atau buruk sama sekali. ${ }^{40}$

Fithrah juga merupakan citra asli yang dinamis. Kedinamisan fithrah terdapat dalam sistem psiko-fisik manusia yang diaktualisasikan dalam perilaku. Fithrah sudah ada dalam diri manusia sejak ia dilahirkan. Manusia, siapa pun orangnya, memiliki fithrah yang sama, meskipun aktualisasi perilakunya berbeda. ${ }^{41}$ Fithrah manusia, sebagaimana perjanjian awal dengan Allah, memiliki sisi yang esensial, yakni menerima amanah menjadi hamba Allah dah khalifahNya di muka bumi.

Dalam konteks pemahaman fithrah persfektif al-Quran, terutama ketika kata fithrah dikaitkan dengan kata yang lain, menurut beberapa ahli, memiliki beberapa makna yang dapat dimunculkan. Pertama, al-Auza'i, sebagaimana yang dikemukakan oleh al-Qurthubi dalam karya tafsirnya yang terkenal, Tafsir alQurthuby, berpendapat bahwa fithrah memiliki makna kesucian (thuhr). Kesucian dalam konteks ini tidak dimaknai bahwa manusia itu netral atau kosong; tidak memiliki kecenderungan baik atau buruk, akan tetapi manusia itu suci secara

${ }^{39}$ Abdul Mujib, Fithrah dan Kepribadian Islam: Sebuah Pendekatan Psikologis, (Jakarta: Darul Falah, 1999)

${ }^{40}$ Ibid.

${ }^{41}$ Abdul Mujib dan Jusuf Mudzakir, Ilmu Pendidikan Islam, (Jakarta: Prenada, 2009), 53 
ISTIGHNA, Vol. 1, No 1, Januari 2018 P-ISSN 1979-2824

Homepage: http://e-journal.stit-islamic-village.ac.id/index.php/istighna

Wari Setiawan

Pendidikan Agama Untuk Anak Berkebutuhan Khusus Prespektif Teori Barat dan Islam

psikis dari dosa dan penyakit rohaniah. ${ }^{42}$ Kedua, al-Baghdadi dalam Tafsir Khazin Musamma Lubab al-Ta'wil fi Ma'ani al-Tanzil, mengemukakan bahwa fithrah merupakan potensi ke-Islaman yang ada pada diri manusia. Pendapat al-Baghdadi ini didasarkan pada pendapat Abu Hurairah yang menyatakan bahwa fithrah adalah beragama Islam. ${ }^{43}$ Ketiga, para ulama mengartikan fithrah sebagai bentuk pengakuan manusia terhadap keesaan Allah; tauhid pada Allah. Manusia memiliki potensi mengesakan Allah sejak ia dilahirkan dan selalu berusaha untuk menemukan dan mencapai ketauhidan yang sejati pada Allah. ${ }^{44}$ Bahkan ketika masih di alam azali, manusia telah memiliki kecenderungan tauhid. Al-Quran memaparkannya sebagai berikut:

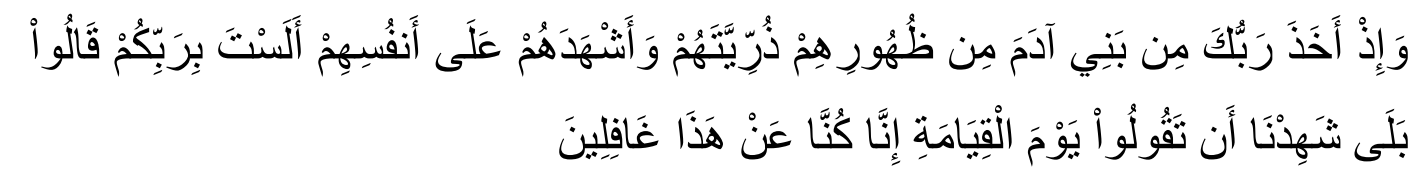

Artinya: "Dan (ingatlah), ketika Tuhanmu mengeluarkan keturunan anak-anak Adam dari sulbi mereka dan Allah mengambil kesaksian terhadap jiwa mereka (seraya berfirman): "Bukankah Aku ini Tuhanmu?" Mereka menjawab: "Betul (Engkau Tuhan kami), kami menjadi saksi". (Kami lakukan yang demikian itu) agar di hari kiamat kamu tidak mengatakan: "Sesungguhnya kami (bani Adam) adalah orang-orang yang lengah terhadap ini (keesaan Tuhan) (QS al-A'raf: 172)

Kelima, Abu Umar ibn Abd al-Bar, sebagaimana dikutip oleh al-Thablawi Mahmud Sa'ad, berpendapat bahwa kata fithrah memiliki makna kondisi yang selamat dan memiliki kontinuitas. ${ }^{45}$ Keenam, al-Thabari dalam tafsirnya, sebagaimana dikemukakan oleh Abdul Mujib dan Jusuf Mudzakkir, menyatakan bahwa fithrah memiliki makna perasaan yang tulus (ikhlash). Manusia lahir membawa sifat baik. Di antara sifat baik tersebut adalah ketulusan dan kemurnian

${ }^{42}$ Al-Qurthuby, Tafsir al-Qurthuby, (Beirut: Dar al-Fikr, t.t), Juz VI, h. 5016

${ }^{43}$ Al-Baghdady, Tafsir Khazin Musamma Lubab al-Ta'wil fi Ma'ani al-Tanzil, (Beirut: Dar al-Fikr, t.t.), jilid III, h. 295; Lihat pula Abdul Mujib dan Jusuf Mudzakir, Abdul Mujib dan Jusuf Mudzakir, Ilmu Pendidikan Islam, (Jakarta: Prenada, 2009), 53

${ }^{44}$ Abdul Mujib dan Jusuf Mudzakir, Loc. Cit., h. 53

${ }^{45}$ Al-Thablawi Mahmud Sa'ad, al-Tashawwuffi Turats Ibn al-Taimiyyah, (Mesir: al-Hai'at al-Mishriyyah al-Ammat li al-Kitab, 1984), h. 102 
ISTIGHNA, Vol. 1, No 1, Januari 2018 P-ISSN 1979-2824

Homepage: http://e-journal.stit-islamic-village.ac.id/index.php/istighna

Wari Setiawan

Pendidikan Agama Untuk Anak Berkebutuhan Khusus Prespektif Teori Barat dan Islam

dalam melakukan setiap aktivitas. ${ }^{46}$ Ketujuh, fithrah berarti ketetapan atau takdir asal manusia mengenai kebahagiaan dan kesengsaraan. Kedelapan, fithrah memiliki makna potensi dasar manusia untuk melakukan aktivitas ibadah kepada Allah. Kesembilan, Langgulung memandang bahwa fithrah berarti sifat-sifat Allah yang dihembuskan pada manusia sebelum ia dilahirkan ke dunia. ${ }^{47}$ Kesepuluh, fithrah diartikan sebagai tabiat atau watak asli manusia (thabi'iyat al-insan/human nature). ${ }^{48}$

Berkaitan dengan pemaknaan fithrah sebagai sifat-sifat Allah yang dihembuskan pada manusia, sifat tersebut berada dalam konteks al-asma al-husna (nama-nama Allah yang indah) yang berjumlah 99. Al-Quran menyatakan,

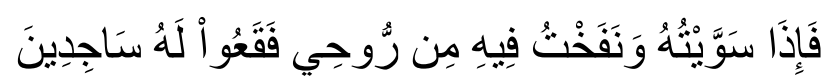

Artinya: "Maka apabila Aku telah menyempurnakan kejadiannya, dan telah meniupkan ke dalamnya ruh (ciptaan) $K u$, maka tunduklah kamu kepadanya dengan bersujud. (QS al-Hijr: 29)

Manusia dalam menjalankan kehidupannya di dunia memiliki tugas mulia untuk mengaktualisasikan al-asma al-husna tersebut dengan sebaik-baiknya dengan cara internalisasi nilai dan sifat tersebut dalam kepribadiannya. Konteks pendidikan mensinyalir hal tersebut. Pendidikan dalam persfektif Islam berusaha mengarahkan dan memberi petunjuk pada manusia untuk menginternalisasikan sifat-sifat yang baik dalam dirinya supaya ia mampu menjalankan fungsi kehidupannya di dunia sebaik-baiknya sebagai hamba Allah dan pemikul amanah khalifah-Nya.

Selain persfektif al-Quran yang digunakan, para ulama turut pula mewarnai pemikiran mengenai leksikologi kata fithrah berdasarkan uraian dan makna yang tertuang dalam hadits Nabi. Makna fithrah yang muncul dalam konteks pemerian redaksi hadits, sebagaimana yang diuraikan oleh Abdul Mujib dan Jusuf Mudzakkir, di antaranya adalah sebagai berikut: pertama, fithrah diartikan sebagai takdir atau status anak yang dilahirkan. Kedua, fithrah merupakan salah satu dari

\footnotetext{
${ }^{46}$ Abdul Mujib dan Jusuf Mudzakkir, Ilmu Pendidikan Islam, Op. Cit., h. 53

${ }^{47}$ Hasan Langgulung, Pendidikan Islam dan Peralihan Paradigma, (Selangor: Hizbi, 1995), h. 122

${ }^{48}$ Abdul Mujib dan Jusuf Mudzakkir, Loc. Cit., h. 54
} 
ISTIGHNA, Vol. 1, No 1, Januari 2018 P-ISSN 1979-2824

Homepage: http://e-journal.stit-islamic-village.ac.id/index.php/istighna

Wari Setiawan

Pendidikan Agama Untuk Anak Berkebutuhan Khusus Prespektif Teori Barat dan Islam

sepuluh kesucian biologis manusia. Ketiga, salah satu asma Allah sebagai Dzat Maha Pencipta. ${ }^{49}$

Juhaya S Praja dalam Jurnal Ulumul Quran menyatakan pendapat Ibn Taimiyyah mengenai pengertian leksikologis fithrah. Menurut Ibn Taimiyyah, fithrah tidak terbatas hanya pada karakteristik yang bersifat religius, namun ia memiliki tiga daya kekuatan yaitu daya intelek (quwwat al-aql), yang merupakan potensi dasar manusia untuk membedakan mana yang baik dan mana yang buruk; daya ofensif (quwwah al-syahwah), yakni potensi dasar manusia untuk menginduksi objek yang menyenangkan dan bermanfaat; dan daya defensif (quwwah al-ghadhab), yaitu potensi dasar manusia untuk menghindarkan diri dari segala perbuatan yang membahayakan dirinya. ${ }^{50}$

Islam sebagai agama universal tidak hanya mementingkan masalah ibadah, namun juga masalah yang lainnya. Islam sangat memperhatikan masalah-masalah yang berhubungan dengan pendidikan. Dalam hal pendidikan, khususnya mengenai anak didik Islam mempunyai pandangan ontologis tersendiri yang tidak dimiliki oleh ajaran agama lain. Pandangan ontologis Islam tentang pendidikan dapat dilihat dari konsep fitrah. Fitrah merupakan elemen dasar yang dimiliki oleh semua manusia, dalam hal ini termasuk pendidik dan peserta didik. ${ }^{51}$

\section{Penutup}

Dua perspektif pemikiran di atas menunjukkan perbedaan yang cukup tajam. Mayoritas teori Barat menegaskan bahwa pendidikan agama tidak mesti diajarkan pada peserta didik, bahkan dalam kaitan model medis ABK tidak diperlakukan sebagai manusia yang punya hak. Mereka dianggap sebagai masalah sosial yang menghambat perkembangan masyarakat. Berbeda dengan perspektif Islam (fithrah), ABK merupakan makhluk Tuhan yang mempunyai potensi. Pandangan optimis terkait fithrah ini menunjukkan bahwa ABK dalam perspektif Islam harus

\footnotetext{
${ }^{49}$ Abdul Mujib dan Jusuf Mudzakkir, Ilmu Pendidikan Islam, Op. Cit., h.55

${ }^{50}$ Lihat Tedi Priatna, Reaktualisasi Paradigma Pendidikan Islam, Bandung: Pustaka Bani Quraisy, 2004), 97

${ }^{51}$ Hartono, Pendidik dan Peserta Didik Dalam Perspektif Filsafat Pendidikan Islam, Jurnal Potensia Vol.13 Edisi 1 Januari-Juni 2014, I97
} 
ISTIGHNA, Vol. 1, No 1, Januari 2018 P-ISSN 1979-2824

Homepage: http://e-journal.stit-islamic-village.ac.id/index.php/istighna

Wari Setiawan

Pendidikan Agama Untuk Anak Berkebutuhan Khusus Prespektif Teori Barat dan Islam

diperhatikan dan dilayani pendidikannya sebaik-baiknya sesuai dengan tipe atau karakteristik ABK.

\section{DAFTAR PUSTAKA}

Abdullah, M. Amin, The Idea of Universality of Ethical Norms In Ghazali and Kant, diterjemahkan oleh Hamzah dengan judul, Antara Al-Ghazali dan Kant: Filsafat Etika Islam, (Bandung: Mizan, 2002)

Abidin, Zainal, Filsafat Manusia, (Bandung: Remaja Rosdakarya, 2002)

al-Ahwani, Fuad, al-Tarbiyah al-Islamiyah. (Kairo: Dar al-Ma'arif, 2008)

Al-Baghdady, Tafsir Khazin Musamma Lubab al-Ta'wil fi Ma'ani al-Tanzil, (Beirut: Dar al-Fikr, t.t.)

al-Ghazali, Muhammad, Nahwa Tafsir Maudhui li Suwari al-Quran al-Karim, (Beirut: Dar al-Shuruq, 2011)

Al-Qurthuby, Tafsir al-Qurthuby, (Beirut: Dar al-Fikr, t.t.)

Aly, Hery Noer, Ilmu Pendidikan Islam, (Jakarta: Logos, 2008)

Anggraeni, Rima Rizki. "Persepsi Orang Tua terhadap Anak Berkebutuhan Khusus”, dalam Jurnal Ilmiah Pendidikan Khusus Vol.1 Nomor 1 Januari 2013

Anis, Ibrahim, Al-Mu'jam al-Wasith, (Kairo: Dar al-Ma'arif, 1972)

Azizy, Qadri, Melawan Globalisasi: Reinterpretasi Ajaran Islam Persiapan SDM dan Terciptanya Masyarakat Madani. (Yogyakarta: Pustaka Pelajar, 2004)

Badri, Sihabu, Teori Psikoanalisis Sigmund Freud, (Bandung: UIN Bandung, 2010)

Bafadal, Fadhal AR., Al-Qur'an dan Tafsirnya, (Semarang: CV. Al Waah, 2004)

Bayrakli, Bayraktar, Eksistensi Manusia: Perspektif Tasawuf dan Filsafat Mengatasi Problema Eksistensial Manusia Jalaluddin Rumi Sampai Filosof Kontemporer, (Jakarta: Perenial Press, 1997)

Damanhuri. Akhlak Perspektif Pemikiran Tasawuf Abdurrauf As-Singkili, (Banda Aceh: Ar-Rijal Publisher, 2011) 
ISTIGHNA, Vol. 1, No 1, Januari 2018 P-ISSN 1979-2824

Homepage: http://e-journal.stit-islamic-village.ac.id/index.php/istighna

Wari Setiawan

Pendidikan Agama Untuk Anak Berkebutuhan Khusus Prespektif Teori Barat dan Islam

Daming, Saharudin. "Komparasi Nilai Penguatan Hak Penyandang Disabilitas dalam Lex Posterior dan Lege Priori”, dalam Jurnal HAM Vol. XIIITahun 2016

Fadjar, A. Malik. Holistika Pemikiran Agama, (Jakarta: Raja Grafindo Persada, 2005)

Harlock. Personality Development, (New York: Mc Millan, 2010)

Hartono, "Pendidik dan Peserta Didik Dalam Perspektif Filsafat Pendidikan Islam, dalam Jurnal Potensia Vol.13 Edisi 1 Januari-Juni 2014

Hermawan, Heris, Filsafat Pendidikan Islam, (Jakarta: Diktis)

Ibn Miskawaih, Menuju Kesempurnaan Akhlak, (Bandung: Mizan, 1994)

Katsir, Ibnu. Tafsir Ibnu Kathir, (Cairo: Dar al-Shabuni, t.th.)

Kemenag, EMIS 2014/2015, (Jakarta: Ditjen Pendis, 2015)

Kemendikbud, Statistik Sekolah Luar Biasa Tahun 2015/2016, (Jakarta: Pusat Data Statistik Pendidikan, 2016)

Kurnali, Pengembangan Pendidikan Agama Islam Sebagai Budaya Dalam Pembentukan Karakter Siswa: Studi Kasus di SMP Islam PB. Soedirman Jakarta, (Magelang: PKBM Ngudi Ilmu, 2014)

Langgulung, Hasan, Pendidikan Islam dan Peralihan Paradigma, (Selangor: Hizbi, 1995)

Madjid, Nurcholish, Islam Doktrin dan Peradaban: Sebuah Telaah tentang Keimanan, Kemanusian dan Kemoderenan. (Jakarta: Paramadina, 1992)

Majdidi, Busyairi, Konsep Kependidikan para Filosof Muslim, (Yogyakarta: alAmin, 1997)

Maskawaih, Ibnu, Tahdzib al-Akhlaq wa Tathir al-'Araq, (Beirut: Mansyurat Dar Maktabah al-Hayat, 1398)

Miri, Jamaluddin, Pendidikan Anak dalam Islam, (Jakarta: Pustaka Amani, 2007)

Mujib, Abdul dan Mudzakir, Jusuf, Ilmu Pendidikan Islam, (Jakarta: Prenada, 2009)

Mujib, Abdul, Fithrah dan Kepribadian Islam: Sebuah Pendekatan Psikologis. (Jakarta: Darul Falah, 1999) 
ISTIGHNA, Vol. 1, No 1, Januari 2018 P-ISSN 1979-2824

Homepage: http://e-journal.stit-islamic-village.ac.id/index.php/istighna

Wari Setiawan

Pendidikan Agama Untuk Anak Berkebutuhan Khusus Prespektif Teori Barat dan Islam

Murata, Sachiko, The Tao of Islam: Kitab Rujukan tentang Relasi Gender dalam Kosmologi dan Teologi Islam, (Bandung: Mizan, 2000)

Musa, Muhammad Yusuf, Falsafah al-Akhlaq fi al-Islam, (Kairo: Muassasat alKanji, 1963)

Nasution, Harun, Pendidikan Agama dalam Perspektif Agama-agama, (Jakarta: Konsorsium Pendidikan Agama di Pertenaga Pendidikan Tinggi Umum, 1995)

Nata, Abuddin, Ilmu Pendidikan Islam dengan Pendekatan Multidisipliner, (Jakarta: Rajawali Press, 2010)

Priatna, Tedi. Reaktualisasi Paradigma Pendidikan Islam, (Bandung: Pustaka Bani Quraisy, 2004)

Qutub, Sayid, Fi Zilali al-Quran, (Beirut: Dar al-Shuruq, 1992)

Ramayulis, Ilmu Pendidikan Islam, (Jakarta: Kalam Mulia, 2006)

Rennison, Nick, Freud and Psychoanalysis, (London: Pdunk, 2010)

Sa'ad, Al-Thablawi Mahmud, al-Tashawwuf fi Turats Ibn al-Taimiyyah, (Mesir: al-Hai'at al-Mishriyyah al-Ammat li al-Kitab, 1984)

Shihab, M. Quraish, Wawasan Al-Quran: Tafsir Maudhu'i Atas Pelbagai Persoalan Umat, (Bandung: Mizan, 1996)

Sulaiman, Umar, Islam Kosmopolit: Ikhtiar Pembumian Nilai-Nilai Transenden dan Humanis di Ruang Publik, (Yogyakarta: Fresh Book, 2012)

Suryadi, Rudi Ahmad, Ghayah al-Tarbiyah fi Dhau' al-Qur'an al-Karim, (Bandung: UIN Bandung, 2011)

Suseno, Frans Magniz. 13 Tokoh Etika, (Yogyakarta: Kanisius, 1997)

Syah, Muhibbin. Psikologi Pendidikan dengan Pendekatan Baru, (Bandung: Rosda Karya, 2007)

Tobroni dan Arifin, Syamsul, Islam Pluralisme Budaya dan Politik: Refleksi Teologi untuk Aksi dalam Keberagamaan dan Pendidikan, (Yogyakarta: Siprres, 1994)

Ulwan, Abdullah Nashih. Tarbiyah al-Aulad fi al-Islam, (Kairo: Darussalam, 1985)

Yusup, Syamsu, Teori Kepribadian, (Bandung: Rosda Karya, 2010) 